\title{
A new harmful thrips species in orange in Antalya Province: Scirtothrips dorsalis Hood (Thysanoptera: Thripidae)
}

\author{
Ekrem ATAKAN , Serkan PEHLIVAN \\ Cukurova University, Agricultural Faculty, Plant Protection Department, Adana, Turkey \\ Corresponding author: E. Atakan, e-mail: eatakan@mail.cu.edu.tr \\ Author(s) e-mail: spehlivan@cu.edu.tr
}

\section{ARTICLE INFO}

Received: October 21, 2021

Received in revised form: November 11, 2021

Accepted: November 16, 2021

\section{Keywords: \\ Chilli thrips \\ Citrus \\ Damage \\ Turkey}

\begin{abstract}
This study discusses the damage of an invasive insect species chilli thrips, Scirtothrips dorsalis Hood (Thysanoptera: Thripidae) on orange trees cv. Washington in the Finike district of Antalya Province, Turkey in 2021. This harmful thrips species was recorded for the first time in a citrus grove in Turkey. Thrips cause inward curling of fresh leaves on the young shoots and also necrosis, mostly silvery-white. The biology, ecology, and control of this species are briefly given.
\end{abstract}

\section{Introduction}

According to USDA (2020) data, in 2019, a total of 92 million tons of citrus fruits were produced in the world, including 46 million tons of oranges, about 32 million tons of tangerines, 8 million tons of lemons, and 7 million tons of grapefruits. The leading countries in the world orange production in 2019 are respectively, according to their production amounts; Brazil (34\%), China (16\%), EU (13\%), and USA (10\%). Turkey ranks 7 th in the world orange production with a production amount of 1.8 million tons. Although Turkey produced approximately 4.3 million tons of citrus fruit in 2019, almost all of the production is provided from the Aegean and Mediterranean Regions. $83 \%$ of Turkey's total orange production, $90 \%$ of tangerine production, $92 \%$ of lemon production, $97 \%$ of grapefruit production is provided from the Mediterranean Region of Turkey (TÜIK 2020).

There are multiple biological factors such as diseases, pests and weeds which can cause economic damage and limit the agricultural yield in citrus. Among the recorded insect species in citrus areas, thrips are recognized as a pest in general. They have been well described with their diverse life histories and habitats, in particular Thysanoptera order, which constitutes $1 \%$ of approximately 6000 thrips species, was reported as a serious pest (Morse and Hoddle 2006; Mound and Morris 2007). The feeding habits of thrips species are quite different, and they can be classified as phytophagous (plant-feeding), mycophagous (fungal-feeding), and predatory species (Morse and Hoodle 2006). Many thrips (Thysanoptera) species have been reported to feed on citrus (Rutaceae) worldwide (Blank and Gill 1997; Childers and Nakahara 2006). These species feed on the flowers, fruits, and leaves of citrus, and their typical damage is in the form of silvery scars. Scars formed on fruits negatively affect the quality of the product and thus reduce its market value (Tekșam and Tunç 2009). The most important pest thrips species attacking citrus; Scirtothrips citri (Moultan) (citrus thrips) and Scirtothrips aurantii Faure (South African citrus thrips) in South Africa (Grove et al. 2000), Scirtothrips dorsalis Hood (Yellow tea thrips) in East Asia (Masui 2007), and Pezothrips kellyanus (Bagnall) (Kelly's citrus thrips) in Australia, New Zealand (Webster et al. 2006; Froud et al. 2001) and two Mediterranean islands in Sicily (Marullo 1998), Southern Cyprus (Vassiliou 2007). Longo (1985) reported that there are more than 40 thrips species which appear in citrus areas in the world. Yet only a few species are harmful such as Scirtothrips spp. and Thrips tabaci Lindeman (Thysanoptera: Thripidae) which are considered pests as they cause scarring on young fruits.

To date, Frankliniella occidentalis (Pergande), Thrips major Uzel (Thysanoptera: Thripidae) and T. tabaci were reported on citrus in Turkey, however they were not taken into account as economically important pests (Nas et al. 2007; Tekşam and Tunç 2009; Ölçülü and Atakan 2013). Tekşam and Tunç (2009) reported that $T$. major was the most common species in citrus fruits in the Antalya Province, and the scarred fruit rates due to thrips was less than $2 \%$. Although $F$. occidentalis occured intensely in the lemon flowers in the Tarsus district of Mersin Province, Turkey, no wound formation on the fruits was observed (Atakan et al. 2016). The Hawaiian flower thrips, Thrips hawaiiensis (Morgan) (Thysanoptera: Thripidae) was recorded for the first time in 'Yediveren' lemons in the Eastern Mediterranean Region of Turkey (Mersin Province) (Atakan et al. 2015), this thrips causes considerable damage to lemon fruits (Atakan et al. 2021). 
On September 12, 2021, in the Antalya Province, Finike district, Turkey, some damage was observed in a orange orchard with Washington variety, especially in young shoots. Collected samples were brought to the laboratory and thrips were detected on shoots and leaves. As a result of the microscopic slides, it has been determined that this species is Scirtothrips dorsalis, also known as chilli thrips or yellow tea thrips, which seriously damaged blueberry plants in Adana Province in 2020 and was recorded for the first time in Turkey (Atakan and Pehlivan 2021). This study provides some brief information about $S$. dorsalis, an important pest of citrus fruits, and the definition of thrips damage investigated in plant samples. It can provide basic information regarding morphological features, damage, ecology and biology of this species, and also contribute to the control studies that must be carried out before it spreads throughout larger areas.

\section{Materials and Methods}

\subsection{Sampling}

Due to the damage observed which was similar to thrips damage especially on the leaves of the fresh shoots of the trees, in an orchard where approximately 20 years old Washington orange trees were planted in Finike, Antalya, on September 12, 2021, leaf samples were taken. The damaged leaves were randomly collected and brought to the Entomology laboratory of the Plant Protection Department of Çukurova University, Adana Province, Turkey.

\subsection{Identification of thrips}

The thrips specimens were collected from the leaves with the help of a fine-tipped brush and placed into tubes containing $60 \%$ ethyl alcohol. Afterwards, the samples were kept in AGA (10 parts $60 \%$ ethyl alcohol, one part glycerin and one part glacial acetic acid) for two days in order to facilitate their preparation by softening their bodies and once achieved, they were reintroduced into $60 \%$ alcohol. The samples were taken separately in glass petri dishes and kept in $10 \%$ potassium hydroxide for about 1 hour at 48 degrees on the hot plate. Body contents were macerated by entering through the hind leg bases of thrips individuals with a fine-tipped needle, cleaned by passing through alcohol series and transferred to a HOYER medium to prepare their microscopic slides. Thrips preparations were kept in an oven at 47 degrees to let them dry (Mound and Kibby 1998). The morphological features of the specimens (male and female individuals) were examined under the stereoscopic microscope (40X) and identified by the first author.

\section{Results and Discussion}

\subsection{Identification and biology}

The images obtained by making the preparations of female and male Scirtothrips dorsalis are shown in Figure 1a, b, and their natural appearance on the leaves is shown in Figure $2 \mathrm{a}, \mathrm{b}$. Adult females are about $1.2 \mathrm{~mm}$ long, with dark wings and dark

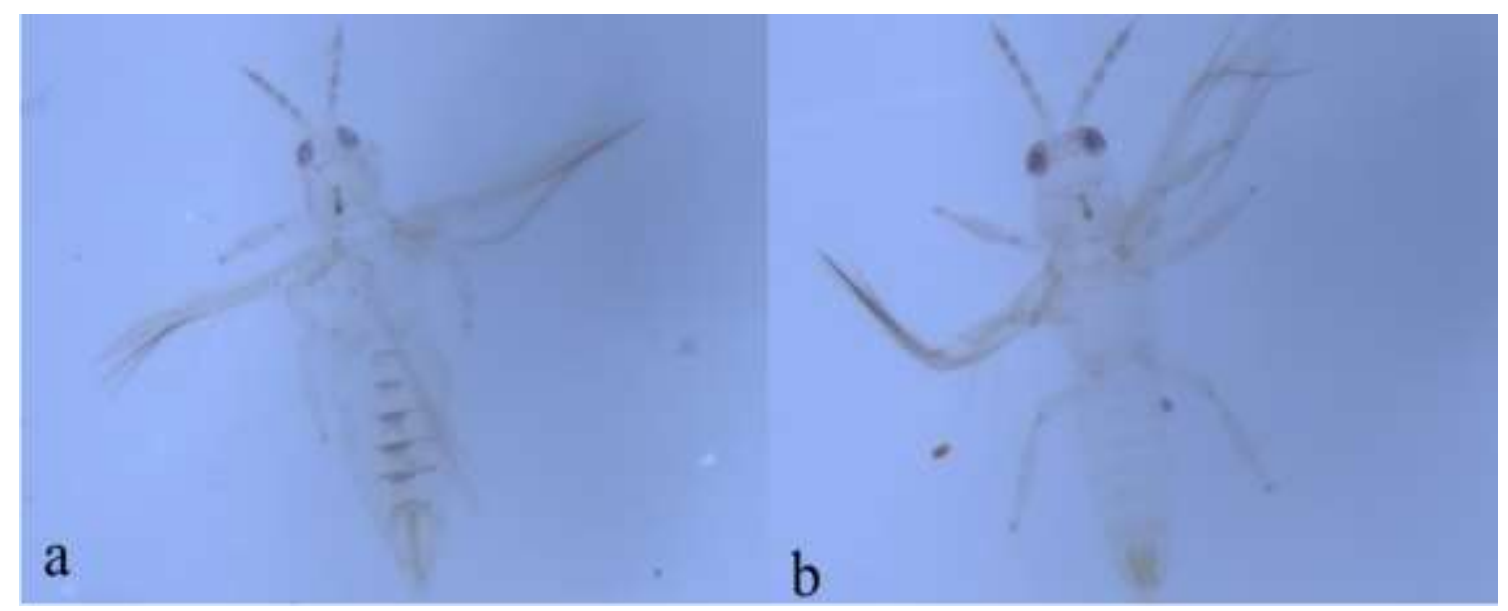

Figure 1. Microscopic slide images of adult female (a), and male (b) Scirtothrips dorsalis (Photo by E. Atakan, 2021).

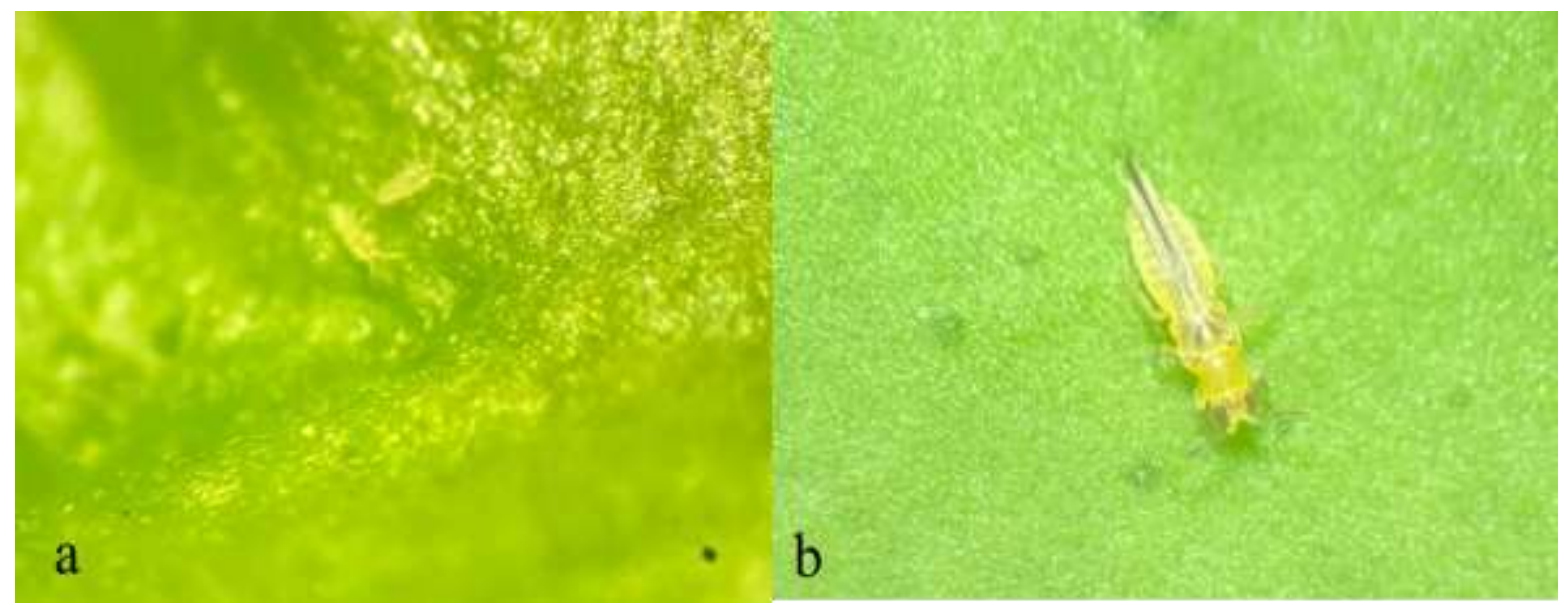

Figure 2. Natural appearances of the larvae (a) and adult female (b) Scirtothrips dorsalis (Photo by L. Bakırcıŏglu Erkılıç, 2021). 
spots on the abdomen forming missing stripes visible on the back (Figure 1a). Adult males are smaller than females, have no spots on the back, and are lighter in colour (Figure 1b). Larvae are transparent or light yellowish in colour (Figure 2a). Detailed morphological diagnosis of the species has been given in a previous study (Atakan and Pehlivan 2021).

Scirtothrips dorsalis eggs are microscopically $0.075 \mathrm{~mm}$ long and $0.070 \mathrm{~mm}$ wide. Eggs are kidney-shaped and creamy white (Seal et al. 2009). Since thrips inserts eggs in plant tissues, it is very difficult to detect its eggs. The eggs hatch in two to seven days, depending on the temperature. Larvae and adults tend to accumulate near the midrib or borders of the host plant. The two larval stages (first and second) are completed in eight to ten days and the pupal stage lasts 2.6-3.3 days. Unlike other thrips, the pupae of this species are usually found on leaves, leaf litter, curled leaves, sometimes hidden under the sepals of flowers and fruits (Seal et al. 2009). Adults and larvae are found in the fresh leaves of the end shoots of trees.

\subsection{Host plants}

Even though $S$. dorsalis caused serious damage to the green parts of the blueberries in a greenhouse in Adana province (Atakan and Pehlivan 2021), no data are available concerning the host habitat of this species in the ecological regions where $S$. dorsalis has been detected in Turkey, up to now. To the best of our knowledge, $S$. dorsalis has been reported to infest a wide variety of host plants belonging to more than 100 plant taxa from 40 families (Mound and Palmer 1981; Venette and Davis 2004; Klassen et al. 2008; Kumar et al. 2013). Although the main hosts of $S$. dorsalis are acacia, mimosa and Saraca (Fabaceae), it has been recorded as a pest on several economically important host plants. For instance, Venette and Davis (2004) listed the potential hosts such as bananas, beans, cashews, citrus, cocoa, maize, cotton, eggplant, grapes, mangoes, melons, peanuts, peppers, strawberries, roses, sweet potatoes, tea, tobacco and tomatoes. Moreover, S. dorsalis is an important pest of ornamental plants in Florida (Klassen et al. 2008; Osborne 2009). Additionally, this thrips was found in 13 of 181 plant species sampled in Colombia, including citrus fruits (Ravelo et al. 2018). When this study was prepared for publication, strawberry leaves were seriously damaged due to $S$. dorsalis in autumn in Adana Province.

\subsection{Damage}

With their sucking mouthparts, adults and larvae of $S$. dorsalis absorb the cell sap of the leaves, causing the leaf to curl upwards and reduce the leaf size. Inward curls on the fresh leaves of the end shoots and also silvery-white necrosis formations are presented in Figure 3. Thrips individuals were not found in the old leaves and fruits of orange trees, and the typical signs of damage were not observed. The damage caused by S. dorsalis feeding may become superficially similar to mite damage (Sanap and Nawale 1987; Seal et al. 2006). In many host plants, after a dense population occurred, thrips started to feed on the upper surface of the leaves.

In this study, S. dorsalis individuals were detected on account of the damage to the shoots of orange trees in September. Presumably, spraying in the early period, especially in the flowering and young fruit period of citrus, may have suppressed the pest thrips. Jae-Wook et al. (2012) reported that $S$. dorsalis peaks in citrus orchards in South Korea (Jeju Island) in July or autumn, producing silver-grey or dark-coloured spots on the fruits. These injured tissues appear as a halo around the fruit stalks. According to that study, the rate of damaged fruit ranged from $0.04 \%$ to $0.09 \%$. Moreover, $S$. dorsalis was reported in citrus fruits in Fars, Iran in 2015 (Minaei et al. 2016). According to that study, the harmful thrips species caused curling and hardening of the leaves on the fresh shoots, and silvery scars on the fruit surfaces of citrus.

\subsection{Control}

Effective control methods for $S$. dorsalis are still in the research phase. Some suggestions including crop rotation, removal of host weeds, and introducing predators or parasitoids have been made by the World Vegetable Center (AVRDC) to control this harmful thrips. Besides, it is always recommended to use insecticides from different classes in order to prevent the development of insecticide resistance. While synthetic pyrethroids can not effectively suppress $S$. dorsalis in pepper (Seal et al. 2006), soil or green parts applications of imidacloprid, one of the neonicothionide group insecticides, provides successful results in the management of $S$. dorsalis without harming beneficial insects (Seal and Kumar 2010). Foliar applications of imidacloprid from the soil much more successful

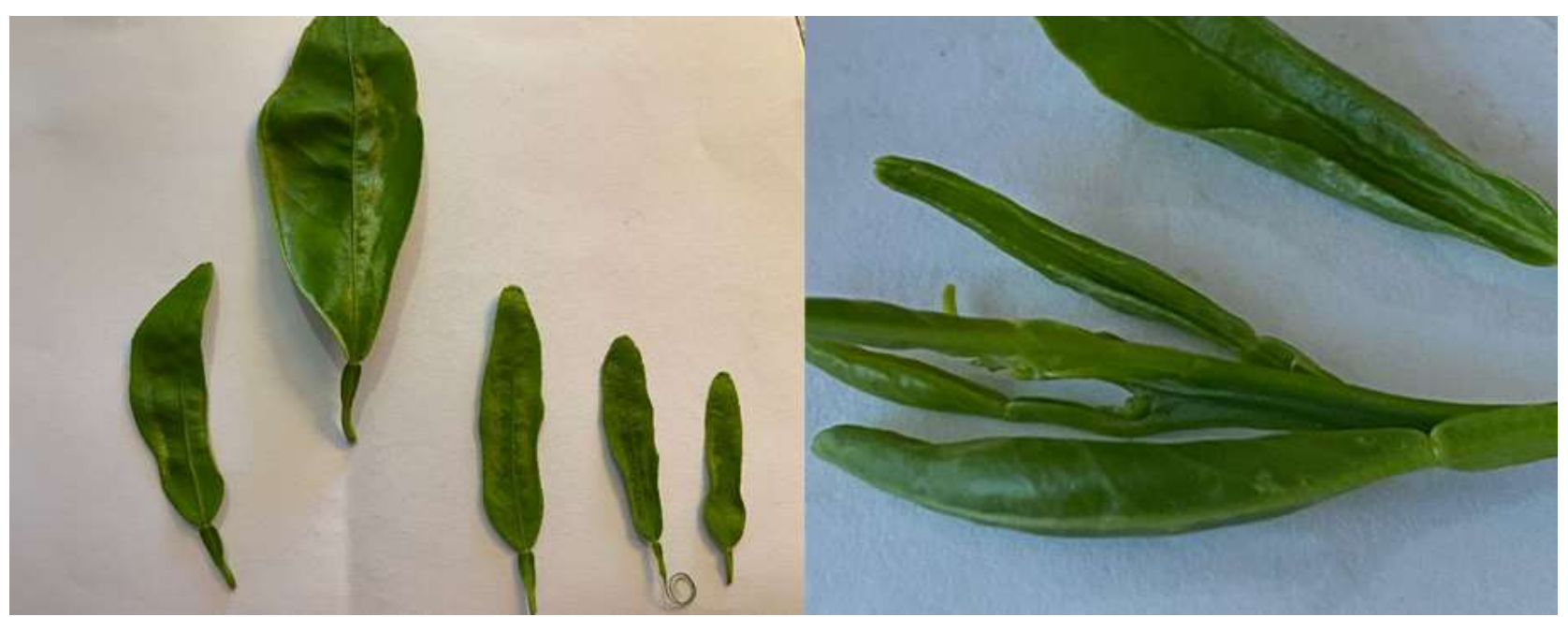

Figure 3. Damage symptoms on orange leaves as a result of feeding of Scirtothrips dorsalis (Photo by L. Bakırcıŏlu Erkı1ıç, 2021). 
(Seal et al. 2008). However, the use of some insecticides from this group (i.e., imidacloprid) is prohibited in Turkey.

On the other hand, predatory Orius species (Hemiptera: Anthocoridae), known as minute pirate bugs, and entomopathogenic nematodes, Thripinema spp. (Tylenchida: Allantonematidae), have been reported to suppress the field populations of the pepper thrips (Kumar et al. 2017). The adults of the insidious flower bug, Orius insidiosus Say (Hemiptera: Anthocoridae), effectively feed on thrips larvae and adults. Even if the thrips populations are greatly reduced, $O$. insidiosus may continue feeding on aphids, mites, moth eggs and pollens, with no significant reduction in population density. Thripinema species, parasitize adult female thrips, significantly reducing their egg production and thus significantly suppressing the thrips population density. Arthurs et al. (2009) evaluated two predatory mites, Neoseiulus cucumeris and Amblyseius swirskii (Acarina: Phytoseiidae) as potential biological control agents of $S$. dorsalis and A. swirskii elicited the promising results in the control of $S$. dorsalis on hot pepper plants. Among the potential predators of thrips: Chrysoperla spp., ladybugs, predatory thrips species such as Franklinothrips vespiformis (Vespiform thrips), Scolothrips sexmaculatus (Six-pointed thrips) (Thysanoptera: Aeolothripidae), Selenothrips rubrocinctus (Giard) (Red banded thrips), Leptothrips mali (Fitch) (Black hunter thrips) (Thysanoptera: Phlaeothripidae) and predatory mites including Amblyseius spp., Euseius hibisci (Chant) and Euseius tularensis Congdon (Acarina: Phytoseiidae) were reported (Arthurs et al. 2009).

\section{Conclusion}

In addition to the invasive $T$. hawaiiensis, which is a problem in lemons in the Eastern Mediterranean Region of Turkey, yet another invasive species, $S$. dorsalis, was recently recorded on orange trees in a limited area in the Finike district of Antalya Province. Except for the location where the first record of this thrips species on a citrus groves was made (locations Finike and Turunçova), this thrips has not been detected yet on the citrus groves in the following locations, Sahilkent, Hasyurt and Kumluca in Antalya Province, where citrus cultivation is common. However, its distribution and economic importance in citrus orchards in the Mediterranean Region of Turkey is not known yet; these basic issues need to be investigated for control efforts. Currently, there are insecticides with temporary licenses against $T$. hawaiiensis in citrus in Turkey. Although the economic importance of newly detected $S$. dorsalis in citrus fruits in Turkey is unknown, T. hawaiiensis continues to be a problem in lemons. Citrus producers randomly apply different groups of insecticides against thrips, mostly in the form of mixtures. In this way, the application of pesticides may cause different ecological problems in citrus ecosystems. Solution suggestions against invasive thrips species that are harmful to citrus fruits should be sought in integrated pest control programs. In this context, there is a need for basic studies on $S$. dorsalis in citrus groves in Turkey.

\section{Acknowledgements}

We would like to thanks to Associate Prof. Dr. Lerzan Bakırcığlu Erkılıç and to Halil Demirbaş (Biological Agriculture Consulting and Engineering Services, Erzin/Hatay, Turkey) for their valuable contributions to the preparation of this manuscript.

\section{References}

Arthurs S, McKenzie CL, Chen J, Dogramaci M, Brennan M, Houben K, Osborne L (2009) Evaluation of Neoseiulus cucumeris and Amblyseius swirskii (Acari: Phytoseiidae) as biological control agents of chilli thrips, Scirtothrips dorsalis (Thysanoptera: Thripidae), on pepper. Biological Control 49: 91-96.

Atakan E, Pehlivan S (2021) First report of the chilli thrips, Scirtothrips dorsalis Hood, 1919 (Thysanoptera: Thripidae) in Turkey. Turkish Journal of Zoology 45(2): 156-160.

Atakan E, Pehlivan S, Achiri TD (2021) Pest status of the Hawaiian flower thrips, Thrips hawaiiensis (Morgan) (Thysanoptera: Thripidae) in lemons in the Mediterranean region of Turkey. Phytoparasitica 49: 513-525.

Atakan E, Ölçülü M, Pehlivan S, Özgür O (2016) An analysis of western flower thrips Frankliniella occidentalis (Pergande) (Thysanoptera: Thripidae) in lemons: Its abundance, distribution and damage status. Journal of Entomological and Zoological Studies 4(2): 109-114.

Atakan E, Ölçülü M, Pehlivan S, Satar S (2015) Türkiye'de yeni zararlı bir thrips türü: Thrips hawaiiensis (Morgan, 1913) (Thysanoptera: Thripidae). Türkiye Entomoloji Bülteni 5: 77-84.

Blank RH, Gill GSC (1997) Thrips (Thysanoptera: Thripidae) on flowers and fruity of citrus in New Zealand. New Zealand Journal of Crop and Horticulture Science 25: 319-312.

Childers CC, Nakahara S (2006) Thysanoptera (thrips) within citrus orchards in Florida: Species distribution, relative and seasonal abundance within trees, and species on vines and ground cover plants. Journal of Insect Science 45(6): 1-19.

Froud K, Stevens PS, Steve D (2001) Survey of alternative host plants for Kelly's citrus thrips (Pezothrips kellyanus) in citrus growing regions. New Zealand Plant Protection 54: 15-20.

Grove T, Giliomee JH, Pringle KL (2000) Seasonal abundance of different stages of the citrus thrips, Scirtothrips aurantii, on two mango cultivars in South Africa. Phtyoparasitica 28(1): 43-53.

Jae-Wook H, Rok-Yeon H, Kwan-Seok L, Jeong-Heub S, Pyoung-Ho Y, Hyeog-Mo K, Dong-Hee H, Kwang-Sik K (2012) Seasonal occurrence of Yellow tea thrips, Scirtothrips dorsalis Hood (Thysanoptera: Thripidae) in citrus orchards and its damage symptoms on citrus fruits. Korean Journal of Applied Entomology 51(1): 1-7.

Klassen W, Seal DR, Ciomperlik MA, Fieselmann DA (2008) The chilli thrips, Scirtothrips dorsalis: current status in the Greater Caribbean Region. Proceedings of the Caribbean Food Crops Society 44: 103117.

Kumar V, Kakkar G, McKenzie CL, Seal DR, Osborne LS (2013) An Overview of Chilli Thrips, Scirtothrips dorsalis (Thysanoptera: Thripidae) Biology, Distribution and Management. In: Soloneski S, Larramendy M (Ed), Weed and Pest Control - Conventional and New Challenges, pp. 53-77.

Kumar V, Seal DR, Kakkar G (2017) Scirtothrips dorsalis Hood (Insecta: Thysanoptera: Thripidae). UF/IFAS, Entomology and Nematology. https://entnemdept.ufl.edu/creatures/orn/thrips/chilli_thrips.htm. Accessed 27 September, 2021.

Longo S (1985) Thrips on citrus groves. Proceedings of Expert Meeting Acireale. In: Cavalloro R, Dimartino E (Ed), Integrated pest control in citrus groves. Balkema, Rotterdam, Boston, pp. 209-216.

Marullo R (1998) Pezothrips kellyanus UN nuovo tripide parassita delle colture. Informatore Fitopatologico 48(10): 72-74.

Masui S (2007) Synchronism of immigration of adult thrips, Scirtothrips dorsalis Hood (Thysanoptera: Thripidae) to citrus orchards with reference to their occurrence on surrounding host plants. Applied Entomology and Zoology 42(4): 517-523.

Minaei K, Bagherian SAA, Aleosfoor M (2016) Scirtothrips dorsalis (Thysanoptera: Thripidae) as a pest of citrus in Fars province, Iran. Iranian Journal of Plant Protection 46: 219-225. 
Morse JG, Hoddle MS (2006) Invasion Biology of Thrips. Annual Review of Entomology 51: 67-89.

Mound LA, Kibby G (1998) Thysanoptera: An Identification Guide. 2nd ed. CSIRO Entomology, Canberra.

Mound LA, Morris DC (2007) The insect order Thysanoptera: classification versus systematics. Zootaxa 1668: 395-411.

Mound LA, Palmer JM (1981) Identification, distribution and host plants of the pest species of Scirtothrips. (Thysanoptera: Thripidae). Bulletin of Entomological Research 71: 467-479.

Nas S, Atakan E, Elekçioğlu N (2007) Doğu Akdeniz Bölgesi turunçgil alanlarında bulunan Thysanoptera türleri. Türkiye Entomoloji Dergisi 31: 307-316.

Osborne LS (2009). Chilli thrips, Scirtothrips dorsalis Hood. http://mrec.ifas.ufl.edu/lso/thripslinks.htm. Accessed 24 September, 2021.

Ölçülü M, Atakan E (2013) Thysanoptera species infesting the flowers of citrus in the eastern Mediterranean region of Turkey. IOBC-WPRS Bulletin 95: 63-69.

Ravelo EE, Vaca JU, Arévalo EP, Delgado L, Díaz MF, Piñeros L, Castro ÁP, Brochero H, Goldarazena A (2018) Presence and distribution of Scirtothrips dorsalis Hood (Thysanoptera: Thripidae) in Colombia. Journal of Insect Science 18(5): 1-10.

Sanap MM, Nawale RN (1987) Chemical control of chilli thrips, Scirtothrips dorsalis. Vegetable Science 14: 195-199.

Seal DR, Ciomperlik M, Richards ML, Klassen W (2006). Comparative effectiveness of chemical insecticides against the chilli thrips, Scirtothrips dorsalis Hood (Thysanoptera: Thripidae), on pepper and their compatibility with natural enemies. Crop Protection 25: 949955.

Seal DR, Klassen W, Kumar V (2009). Biological parameters of chilli thrips, Scirtothrips dorsalis Hood, on selected hosts. Environmental Entomology 39(5): 1389-1398.
Seal DR, Kumar V (2010) Biological response of chilli thrips, Scirtothrips dorsalis Hood (Thysanoptera: Thripidae), to various regimes of chemical and biorational insecticides. Crop Protection 29(11): 1241-1247.

Seal DR, Kumar V, Klassen W, Sabine K (2008) Response of chilli thrips, Scirtothrips dorsalis, and melon thrips, Thrips palmi, to some selected insecticides. Proceedings of the Caribbean Food Crops Society 44: 578.

Tekşam İ, Tunç İ (2009) An analysis of Thysanoptera associated with citrus flowers in Antalya, Turkey: Composition, distribution, abundance and pest status of species. Applied Entomology and Zoology 44: 455-469.

TÜİK (2020) Türkiye İstatistik Kurumu, Bitkisel Üretim İstatistikleri. http.//www.tuik.gov.tr. Accessed 4 October, 2021.

USDA (2020) Citrus: World Markets and Trade. US Department of Agriculture, Foreign Agricultural Service. https://www.fas.usda.gov/data/citrus-world-markets-and-trade. Accessed 24 September, 2021.

Vassiliou VA (2007) Chemical control of Pezothrips kellyanus (Thysanoptera: Thripidae) in citrus plantations in Cyprus. Crop Protection 26(10): 1579-1584.

Venette RC, Davis EE (2004) Chilli thrips/yellow thrips, Scirtothrips dorsalis Hood (Thysanoptera: Thripidae). Mini Pest Risk Assessment. University of Minnesota, St. Paul, MN, USA, pp. 31.

Webster KWP, Cooper P, Mound LA (2006) Studies on Kelly's citrus thrips, Pezothrips kellyanus (Bagnall) (Thysanoptera: Thripidae): sex attractants, host associations and country origin. Australian Journal of Entomology 45(1): 67-74. 